\title{
Implementing International Refugee Law in the People's Republic of China
}

\author{
Abdul Knowles \\ Beijing University of Chemical Technology, Beijing, China \\ Email: knowlesad1@gmail.com
}

How to cite this paper: Knowles, A. (2018). Implementing International Refugee Law in the People's Republic of China. Beijing Law Review, 9, 67-74. https://doi.org/10.4236/blr.2018.91005

Received: February 11, 2018

Accepted: March 11, 2018

Published: March 14, 2018

Copyright $\odot 2018$ by author and Scientific Research Publishing Inc. This work is licensed under the Creative Commons Attribution International License (CC BY 4.0).

http://creativecommons.org/licenses/by/4.0/

\begin{abstract}
China's implementation of international refugee law and its asylum policies have long been of interest to numerous state and international non-state actors, especially regarding specific migrant groups in China. Despite China's high regards for international refugee law and a firm belief in the importance of international protection of refugees and asylum-seekers, international observers often argue that China is not meeting its legal obligations under international refugee law. The finding of this research is, despite China's past implementation of favorable asylum policies, and improvements in its application of international refugee law, including the beginning stages of drafting a national refugee law; there remains a gap between China's implementation of international refugee law and international norms. Thus, reforms are needed in China's asylum practices so that it is consistent with international practices. One key factor for this gap is, China's current legal framework and policies do not offer a long-term and durable solution for some refugees and asylum-seekers. Additionally, its asylum framework does not provide all conditions expected of a State that is a party to the "Refugee Convention". Furthermore, China's asylum policies differ among "persons in need of protection" regarding treatment and reception policy. The next crucial step for China in implementing international refugee law should be completing the drafting and adoption of national refugee law that is in line with the "1951 Refugee Convention" and “1967 Protocol”.
\end{abstract}

\section{Keywords}

Refugees, Asylum-Seekers, Refugee Convention, International Human Rights Laws, Indochinese, North Korean Migrants 


\section{Introduction}

\subsection{The Introduction and Background}

As of June 2017, 65.6 million people in the world were forcibly displaced from their homes. According to United Nations High Commissioner for Refugees (hereinafter "UNHCR") ${ }^{1}, 22.5$ million of these persons were refugees ${ }^{2}$. Since 1951, when the international community established the "United Nations Convention relating to the Status of Refugees" ("Refugee Convention"), many countries have come to recognize, respect and adopt this international legislation. Over time and with the emergence of new situations concerning refugees, a "Protocol relating to the Status of Refugees" ("1967 Protocol") was entered into force on 4 October 1967. The "1951 Convention" and "1967 Protocol" (collectively referred to as the "Refugee Convention") ${ }^{3}$ are the principle international instruments that have been established for the protection of asylum seekers and refugees. For this research, the use of the term "asylum-seeker" refers to the UN High Commissioner for Refugees (UNHCR) definition which defines "asylumseekers" as people who flee their own country and seek sanctuary in another country, they apply for asylum - the right to be recognized as a refugee and receive legal protection and material assistance. An asylum seeker must demonstrate that his or her fear of persecution in his or her country is well-founded. The term "refugee" is also based on UNHCR's definition that is defined as someone who has been forced to flee his or her country because of persecution, war, or violence. A refugee has a well-founded fear of persecution for reasons of race, religion, nationality, political opinion or membership in a particular socials group. Most likely they cannot return home or are afraid to do so.

The People's Republic of China [henceforth Mainland China] has acceded the “1951 Refugee Convention" and its "1967 Protocol” but with reservations. While accession to the "Refugee Convention" and its "1967 Protocol" is a significant step towards protecting "persons in need of protection," China has been accused of not effectively implementing the "Refugee Convention." Becoming a signatory of the "Refugee Convention" is a significant step towards protecting refugees and asylum seekers.

Around the time China began implementing its unprecedented "opening and reform" economic policies in the late-1970s, China experienced its largest massmovement of asylum-seekers. Due to conflict with Vietnam in 1978, 275,000 Indochinese, currently, China's largest refugee group began crossing the SinoVietnam border. In the late 1970s, China's Central Committee decided to substantially increase the role of market mechanisms in the system and reducing

\footnotetext{
${ }^{1}$ United Nations High Commissioner for Refugees ("UNHCR") which is governed by the UN General Assembly and the Economic and Social Council (ECOSOC) is the main international refugee agency mandated to work "until the refugee problem is solved," available at www.unhcr.org ${ }^{2}$ United Nations High Commissioner for Refugees (UNHCR), UNHCR Figures at a Glance. ${ }^{3}$ United Nations Convention Relating to the Status of Refugees, July 28, 1951, 189 U.N.T.S. 137 (entered into force Apr. 22, 1954); Protocol Relating to the Status of Refugees, adopted Jan. 31, 1967, 19 U.S.T. 6223, 606 U.N.T.S. 267 (entered into force Oct. 4, 1967).
} 
government planning and direct control. The first reforms consisted of opening trade with the outside world. This included instituting the household responsibility system in agriculture, by which farmers could sell their surplus crops on the open market. Furthermore, this involved the establishment of Town Village Enterprises ${ }^{4}$. Besides witnessing unprecedented economic growth, China has continued to experience rapid economic and legal reforms, a trend that continues. With this trend and being the World's second largest economy, China will experience a growth in the number of refugees and asylum seekers. Francis Teoh, a Beijing-based UN High Commissioner for Refugees (UNHCR's) Senior Regional Officer interviewed for this research believes many asylum-seekers, some from neighboring States with China, such as Myanmar and Pakistan have long shunned China. Instead, many sought asylum in other states in the AsiaPacific region, such as Singapore, Malaysia, Indonesia, Japan, and Australia. For example, the 800,000 Rohingya minority group, currently classified as "Stateless" by the United Nations, that have fled Myanmar in recent years, usually sought asylum in countries other than China. However, this has changed given China's economic prosperity. An increasing number of Rohingya seeks protection within the Chinese border. Desperate to flee persecution in their homeland coupled with China's proximity to these States and its continued economic growth, China will see asylum claimants from other countries beyond its borders.

With an increasing number of asylum seekers, and with encouragement and support from both UNHCR, Chinese legal scholars and researchers, China has

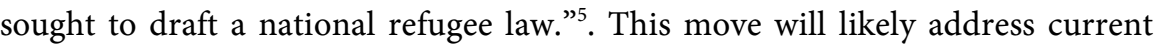
and past asylum issues, such as those of Indochinese refugees that have resided in China for more than thirty years but still lack certain rights afforded them under international refugee law. While completing its drafting a national refugee law would be a significant step forward for China in the further implementation of the international refugee law, it is important that this law mirrors the "Refugee Convention" to ensure consistency with international practice as discussed below.

\subsection{Challenges and Suggestions for Implementing International Refugee Legislation in China}

As a sovereign State, China had a right to accept or reject the "Refugee Convention." However, as a responsible international actor, China decided to become a signatory to the "Refugee Convention." However, full implementation of its provisions has been a challenge for China due to complex geopolitical reasons. Currently, China's good relations with North Korea and Myanmar risk easily influencing China's position to effectively implement international refugee. Since the founding of China, North Korea has been a key ally, a relationship stressed by late Chinese Leader Mao Zedong who often said: "China and North Korea are as close as “lips and teeth” (中朝唇齒相). This fact, as well as China’s bilateral

${ }^{4}$ China Economic Reform Line, Center For Strategic \& International Studies, (http://csis.org/blog/china-economic-reform-timeline).

${ }^{5}$ Francis Teoh, Beijing-based Senior Regional Protection Officer (2012). 
treaty with North Korea which calls for the repatriation of defectors, remains a dilemma in China's obligations to protect under international laws protecting refugees and asylum-seekers. Therefore, in addition to deterring further illegal migrants from crossing its border, China's policy of expelling North Korean asylum seekers and migrants is in an effort to "save face" and preserve its relationship with North Korea. China's good relations with Myanmar has recently led to China drawing a three-stage path for Myanmar in resolving its current Rohingya crises.

One of the key accusations by the UN and other international actors regarding China's implementation of international refugee law stems from the legal principle of non-refoulment, a legal principle international commenters believe China violates when it repatriates North Korean migrants and Burma's Kachin asylum-seekers back to their country of origins. The lack of a fair hearing and refoulment of these persons are reasons for much of the public outcry regarding China's asylum practices and procedures. International observers argue, forced repatriation of bona-fide asylum-seekers face possible incarceration, torture, and abuse. Chinese authorities counter-argue, bona-fide asylum-seekers receive a fair hearing, and refugees receive equal treatment, a claim boasted by Chinese Foreign Ministry spokesperson that stated during a press conference:

“... Since the conflict broke out, some residents (of Burma) living in the border are have come to China to live with their friends and relatives temporarily. China provides them with necessary assistance in conformity with common practices on the basis of humanitarianism." 6

This conflicts with views of international actors who argue, when asylum-seekers are granted protection in China, conditions, and welfare differ among refugee groups and are usually subpar in most cases. Indochinese refugees that have resided in China since 1978 and live primarily in Southern local cities and towns generally receive better housing and welfare, and in some cases, other benefits given to a local Chinese national, such as healthcare and education. However, Kachin refugees and asylum-seekers lack basic welfare afforded to refugees and asylum-seekers under international refugee law and live in jungle camp-like settlements

Despite the origin of asylum-seekers and refugees, Chinese authorities, like all countries that see asylum-claimants and refugees question the legitimacy of some asylum seekers within its border. There are growing concerns in China that some refugee groups and asylum seekers engage in criminal activities such as prostitution and drug trafficking that threatens public security. In some cases, refugees from Indo-China that reside China's Guangxi province, which has the largest Indo-Chinese population, have contracted HIV due to prostitution ${ }^{7}$. Be${ }^{6}$ Chinese Foreign Ministry Spokesperson Hong Lei's Regular Press Conference on June 16, (2011), (http://www.fmprc.gov.cn/eng/xwfw/s2510/2511/t832130.htm).

${ }^{7} \mathrm{Wu} \&$ Liang (2010) Nanmin Wenti Shi Yingxiang Zhongguo Bianjing De chu Shehui Wending de Youyin [Refugee Problem is affecting Social Stability Incentive in China Border Areas], Yunnan Jing Guan Xueyuan Bao [Journal of Yunnan Police Officer Academy]. 
sides, there are risks associated with granting bogus asylum claimants, protection.

In sum, friendships with its neighbors, bi-lateral treaties, public security and its desire for regional stability are some challenges Chinese authorities take into consideration before full implementation of the Refugee Convention.

\subsection{Effectiveness of Implementing International Refugee Law in China}

Due to challenges, one can easily doubt whether China could effectively implement international refugee law. However, geopolitical, existing bi-lateral treaties, public security concerns, and regional stability should not be ignored and should be taken into consideration when implementing international refugee law. China can effectively implement international refugee law, which includes drafting a national refugee law; however, it should do so with "Chinese characteristics." That is, with the Refugee Convention serving as the backbone of its national law, it should include provisions that allow it to preserve existing agreements and its national interest. For example, China should maintain its 1961 treaty with North Korea $^{8}$ which not only aims to safeguard peace between both countries but, peace in Asia and the international community (Article 1). Furthermore, China has huge economic interests in North Korea. Should it disregard the treaty and should the North Korean regime collapse, not would an influx of refugees cross the Sino-Korean border putting pressure on local communities, but, would hurt China's economy due to its trade ties and vast commercial interests with the DPRK. Such approach is not uncommon with countries with mutual agreements and trade interests. For example, although the United States says it abides by China's "One-China Policy",' which acknowledges the People's Republic of China (PRC) is the sole legal government of China, and Taiwan is an inalienable part of the PRC, the United States try to balance its relationship with China and its obligations with Taiwan. It maintains it's 1979 Taiwan Relations Act, which not only aims to aid Taiwan in conflict but, protects the United States' commercial interest and trade relationship with Taiwan, which in 2017 reached $\$ 53.1$ billion ${ }^{10}$. Therefore, with balance, i.e., carefully factoring in its national interests, China can effectively implement international refugee law, which includes efficiently drafting a national law that benefits all asylum-seekers and refugees within its border.

\subsection{Towards Protection}

The cost of China not fully implementing international refugee law and granting asylum to legitimate claimants could be higher. China's status as a Member State

${ }^{8}$ Treaty of Friendship, Co-operation and Mutual Assistance between the People's Republic of China and the Democratic People's Republic of Korea, July 11, 1961.

${ }^{9}$ China Issues Statement on Taiwan Election, Ministry of Foreign Affairs of the People's Republic of China.

${ }^{10}$ Foreign Trade, Trade in Goods with Taiwan; United States Census Bureau. 
of the "Refugee Convention" is an important step towards protecting refugees and asylum-seekers. However, it is important China moves towards full implementation of the "Refugee Convention" and not just simply full ratification because ratification of international treaties does not automatically become a part of domestic law per "The Legislation Law of the People's Republic of China" (Legislation Law of the People's Republic of China, adopted April 29, 2000, entry into force September 1, 2000) states that international protocols can only be enforced if written into domestic law (Article 8) ${ }^{11}$.

Currently, there are provisions in various domestic Chinese laws for the protection of refugees and asylum seekers. Article 46 of the "Foreigners applying for refugee status may, during the screening process, stay in China on the strength of temporary identity certificates issued by public security organs; foreigners who are recognized as refugees may stay or reside in China on the strength of refugee identity certificates issued by public security organs," (Entry and Exit Administration Law of the People's Republic of China," adopted at the $27^{\text {th }}$ meeting of the Standing Committee of the Eleventh National People's Congress on June 30, 2012, entry into force on July 1, 2013). However, there are two primary issues. First, these provisions are narrow in scope. For example, Article 32 of the 1982 Constitution of the People's Republic of China permits one to seek asylum for persecution based solely on political reasons. According to Article 32: "The People's Republic of China may grant asylum to foreigners who request it for political reasons," Constitution of the People's Republic of China, Adopted on December 4, 1982. In contrast, the "Refugee Convention" permits one to seek asylum on numerous reasons, including, persecution based on race, religion, nationality, membership of a particular social group or political opinion (Article 1(A) 2, 1951 Refugee Convention and 1967 Protocol Relating to the Status of Refugees). Secondly, provisions protecting refugees and asylum-seekers in China are dispersed in different legal documents, including the "Exit-Entry Administration Law of the People's Republic of China." It would be convenient and efficient should China include these provisions in domestic law, i.e., complete it's drafting of national refugee law. Thus, it would be clear to those implementing this law.

China needs to continue its current work with and support the UN refugee agency, UNHCR. Currently, UNHCR and Chinese authorities work together on numerous issues involving the protection of refugees and asylum-seekers, including the processing of asylum cases and the drafting of national refugee law. UNHCR is allowed by Chinese authorities to conduct "Refugee Status Determination" (RSD) procedures, a major part of its work. Should China have a national refugee law and adopt policies in line with international, "RSD" procedures, would also be conducted by Chinese authorities in assessing claims. China ${ }^{11}$ Article 8 determined which laws are adopted by the National People's Congress as per Article 7 of the Treaty Procedure Law. Article 7 provides: "The ratification of treaties and important agreements shall be decided upon by the Standing Committee of the National People's Congress," Law of the People's Republic of China on the Procedure of the Conclusion of Treaties, Adopted December 28, 1990. 
should also allow UNHCR access to all areas frequented by asylum-seekers. By granting UNHCR unimpeded access to all areas of China where there are "persons of concern," Chinese authorities would learn firsthand how to carry out "RSD" procedures in all settings effectively. Furthermore, China would further implement the "Refugee Convention" which provides that Member States cooperate with the UNHCR, (Article 35 of United Nations Convention Relating to the Status of Refugees, July 28, 1951, 189 U.N.T.S. 137 (entered into force Apr. 22 , 1954). China's highest annual contribution to UNHCR to-date is still far short of contributions given by industrialized nations. As the second largest World Economy, as of February $6^{\text {th }}, 2018$, China was not among the top 10 government donors to The UN Refugee Agency (UNHCR). Although China's contributions increase annually, its current total contribution as of February 9, 2018, was $\$ 889,118$ USD $^{12}$ putting its donor ranking per capital at \#41. This is far below its neighbor, South Korea, February 9, 2018, total contribution of $\$ 16,621$, 779 USD and \#18 donor ranking ${ }^{12}$.

It is important that international actors and western powers commend and offer support to China for its efforts in refugee and asylum protection rather than try to tarnish China's international reputation. Because of geopolitical concerns and implications, China uses a unique approach to asylum issues, something not readily discussed. Many asylum claims, including those regarding North Koreans, are handled behind closed doors and thus seldom publicized. Although there are occasional flaws in China's implementation of both national and international laws pertaining to refugee issues, international observers should remember that industrialized nations critical of China lack exemplary records in implementation. The United States, a staunch critic of China's human rights record and its handling of North Korean migrants, has had an appalling record protecting certain migrant groups, including its poor handling and treatment of Haitian migrants in the 1980s. According to US Supreme Court Justice, Clarence Thomas, the United States' poor handling of Haitian migrants I the 1980s was an issue that kept him up at night. Besides, currently, many European nations have poor records in managing among many matters pertaining refugees and asylum cases, the 2012 Syrian refugee crisis.

\section{Conclusion}

China should be commended as being one of a handful of states in Asia that is a Member State of the "1951 Refugee Convention" and its "1967 Protocol." Industrialized nations critical of China's asylum policies should remember the complex challenges it faces with its asylum system and implementation of international laws. China's current laws do offer some form of protection to refugees and asylum seekers; however, they are limited in scope. China's current immigration law and policies do not provide a durable long-term solution for immigrants, such as enabling them to become permanent residents or naturalized.

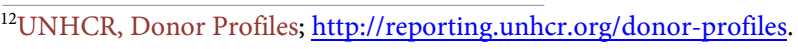


Therefore, China needs to implement international refugee law (Refugee Convention) since it offers uniform protection to refugees and asylum-seekers worldwide. Doing so not only addresses its current and refugee and asylumseeker issues but, will shed light on some national concerns local authorities have regarding refugees and asylum-seekers such as crime, including people smuggling and illegal immigration. Furthermore, as a leader in China, a fully implemented international refugee and national law, would further enhance China's credibility as a global power committed to global causes. This article gives one a better understanding of China's progress and challenges it face in implementing international law. By pinpointing some areas of concern, provides information for consideration, to Chinese policy-makers and authorities tasked with drafting and implementing the Refugee Convention and national refugee law. Also, by addressing its challenges and effectively implementing international refugee law, China's experience can serve as a model for its neighbors and other countries with similar challenges or non-existent refugee legal framework.

\section{References}

China Economic Reform Line, Center for Strategic \& International Studies. http://csis.org/blog/china-economic-reform-timeline

China Issues Statement on Taiwan Election, Ministry of Foreign Affairs of the People's Republic of China. www.fmprc.gove/mfa_eng/wjdt_665385/2649_665393/t15789/shtm

Chinese Foreign Ministry Spokesperson Hong Lei’s Regular Press Conference on June 16, 2011. http://www.fmprc.gov.cn/eng/xwfw/s2510/2511/t832130.htm

Treaty of Friendship, Co-Operation and Mutual Assistance between the People's Republic of China and the Democratic People's Republic of Korea, July 11, 1961. Peking Review, 4, 5. https://www.marxists.org/subject/china/documents/china dprk.htm

UN High Commissioner for Refugees (UNHCR), Protecting Refugees. A Field Guide for NGOs, UNHCR and NGO, September 1999.

http://www.refworld.org/docid/3c03682d4.html

UNHCR. Donor Profiles. http://reporting.unhcr.org/donor-profiles

United Nations High Commissioner for Refugees (UNHCR). UNHCR Figures at a Glance. http://www.unhcr.org/en-us/figures-at-a-glance.html

United States Census Bureau. Foreign Trade, Trade in Goods with Taiwan. https://www.census.gog/foreign-trade/balance/c5830.html

Wu, X., \& Liang, P. Y. (2010). Nanmin Wenti Shi Yingxiang Zhongguo Bianjing De chu Shehui Wending de Youyin [Refugee Problem is affecting Social Stability Incentive in China Border Areas]. Yunnan Jing Guan Xueyuan Bao [Journal of Yunnan Police Officer Academy], 8. 